\title{
Determination of the Optimum Hybrid Renewable Power System: A case study of Istanbul Gedik University Gedik Vocational School
}

\author{
O. AKAR, U. K.TERZI, T. SONMEZOCAK and B. K. TUNCALP
}

\begin{abstract}
In this study, Hybrid Renewable Power System (HRPS) has been designed to meet the energy requirement of Istanbul Gedik University Vocational School (IGUVS) in an optimum way. The energy requirement will be achieved mainly with wind and solar power generation system. The hybrid regenerative power system will be requested from the network when it can't meet its energy needs. The optimum configuration of grid-connected solar/wind hybrid power generation system will be determined by considering the wind speed data and solar radiation data of the location of IGUVS. Moreover, sensitivity analysis will be carried out taking into consideration the wind speed and solar radiation values. If the optimum hybrid power generation system specified is used, the carbon emission values obtained will be examined.
\end{abstract}

Index Terms-Building Based Renewable Energy Sources; Hybrid Power Systems; Distributed Generation.

\section{INTRODUCTION}

$\mathrm{T}$ ODAY, the production and consumption of energy have become a global problem worldwide, which is an independent problem that every country is experiencing.

Onur AKAR, is with Department of Electronics and Automation, Gedik Vocational School, Istanbul Gedik University, Istanbul, Turkey,(e-mail: onur.akar@gedik.edu.tr ).

iD https://orcid.org/ 0000-0001-9695-886X

Umit K. TERZI, is with Department of Electrical-Electronics Engineering Technology Faculty, Marmara University Istanbul, Turkey, (e-mail: terzi@marmara.edu.tr).

(iD https://orcid.org/0000-0001-6739-7717

B. Koray TUNCALP, is with Department of Electrical Electronics Engineering University of Halic, Istanbul, Turkey, (e-mail: koraytuncalp@halic.edu.tr).

(iD) https://orcid.org/ 0000-0003-1632-8900

Temel SONMEZOCAK, is with Department of Electricity and Energy, Gedik Vocational School, Istanbul Gedik University, Istanbul, Turkey,(email: temel.sonmezocak@gedik.edu.tr).

(iD) https://orcid.org/0000-0003-4831-9005

Manuscript received August 12, 2019; accepted October 16, 2019. DOI: $\underline{10.17694 / \text { bajece. } 623632}$
$75.5 \%$ of the world's energy sources are fossil-based conventional energy sources. Due to factors such as the depletion of conventional energy sources in recent years, the generation of carbon emissions from these sources and the emission of greenhouse gases, countries have begun searching for alternatives to meet their energy needs. When countries plan their energy policies, they are mainly concerned with two critical parameters [1-3]. These are ensuring the use of renewable energy sources and taking measures for efficient use of energy. To benefit from renewable energy sources, the potential of renewable energy sources (wind, solar biomass, hydraulics, etc.) must be sufficient. The feasibility study should be carried out for whatever renewable energy source is used before making an investment decision [4]. Another parameter is to determine the policies that will enable us to avoid unnecessary energy consumption through the efficient use of energy. The share of energy consumed in buildings in the world can reach $45 \%-50 \%$ of the total energy consumption of the countries. It is critical to construct buildings that consume less energy nowadays due to factors such as the energy crisis since the 1970s and the effect of the increase in the unit cost of energy resulting from the constantly increasing energy production costs to the end users $[5,6]$. It is projected by the international energy authorities that the use of renewable energy will steadily increase [7, 8]. Countries, especially developed countries, are creating energy maps to identify their potential for renewable energy sources. Renewable energy sources-based energy generation systems can generate power both as part of or independent of national networks. Many buildings use hybrid power generating systems, some independent of national network but more commonly supported by the national network. Therefore, each building must be transformed into an active structure that can produce its own energy, instead of being a passive energy consumer [9]. As it is well known, the biggest handicap of renewable energy sources is the lack of continuity. This discontinuity problem stems from the fact that the energy produced by the renewable energy sources depends on the natural conditions [10]. It is not always possible to achieve continuity of energy produced from one source. It is thought that this problem will be minimized by the hybrid energy system by using more than one renewable energy source together $[11,12]$. 
If the choice of renewable energy sources to be used on the buildings is made by taking into account the geographical location and climate conditions of the building with technical and economic analysis, the buildings may produce part of or all of their energy needs and may even be able to produce more than their own need and reduce the demand on the national network. Moreover, the transfer of excess of the generated electricity to the interconnection network with auxiliary technical equipment provides economical benefits to both the producers and the countries.

\section{USE OF RENEWABLE ENERGY SOURCES IN BUILDINGS}

\section{A. Electricity Generation in Building Shell with PV Panels}

PV panels were first applied to the buildings as an additional system in 1981, and later PV panels were produced which can be used directly as the roof covering. Since 1992, R\&D studies have shown that PV panels can be used effectively in building vertical shells, and pilot applications are increasingly used in the form of building facades [13]. Nowadays PV panels can be produced in two different kinds, semi-permeable or opaque, and various colors. In practice, PV panels are applied directly on the roof, vertical walls and auxiliary areas such as rain covers or sun shades [9]. In Fig. 1 (a), the usage area of PV materials on the building is shown hierarchically.

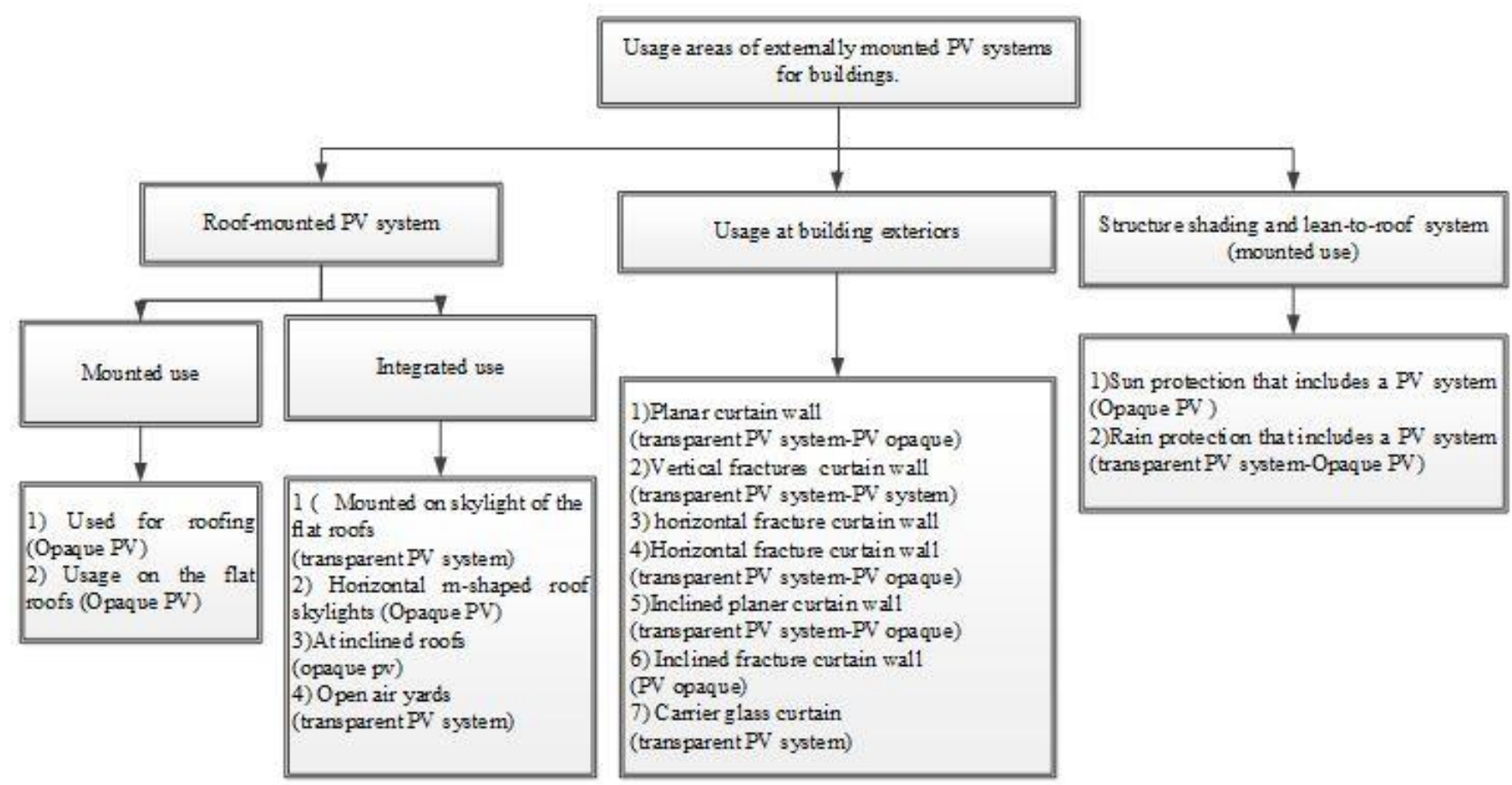

(a)

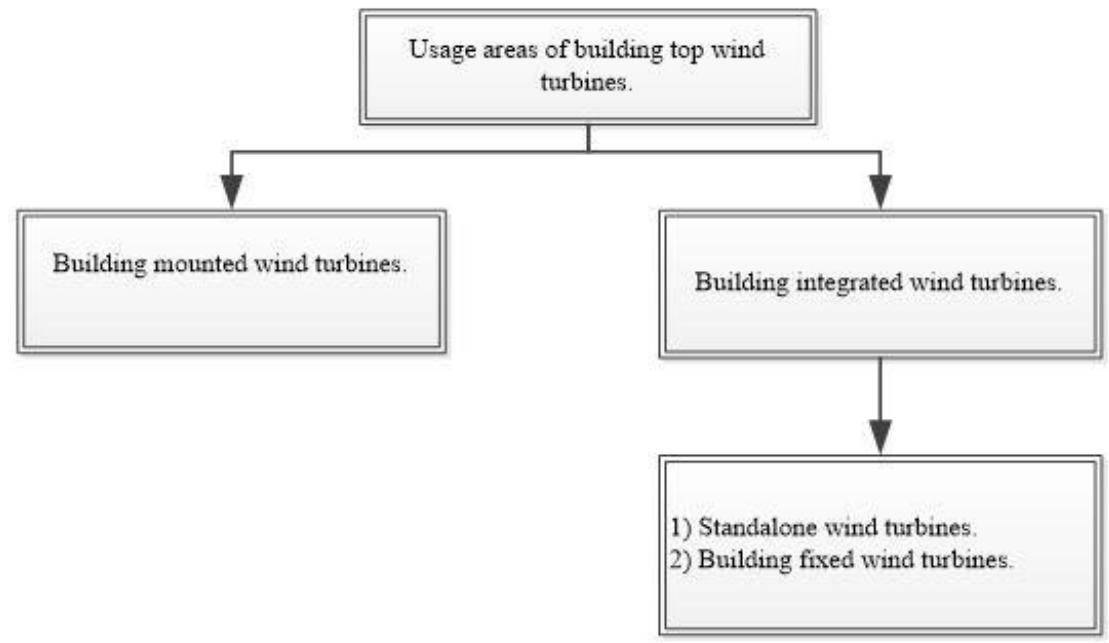

(b)

Fig.1. (a)Usage areas of externally mounted PV systems for buildings (b) Usage areas of building top wind turbines. 


\section{B. Electricity Generation in Building Shell with Wind Generator}

Medium and small-scale horizontal and vertical axis wind turbines are used in the buildings. Wind turbines can be located at a suitable point in the surroundings of the building, or they can be placed in the horizontal shell (roof) of the buildings. There are many applications for the use of integrated wind turbines in high buildings such as multi-story skyscrapers or residences [10]. Small-scale wind turbines have nominal generation values ranging from $50 \mathrm{~W}$ to $20 \mathrm{~kW}$. At low wind speeds, these turbines continue to produce electricity at lower values [14]. As shown in Fig. 1 (b), wind turbines are placed on buildings either as an integral part of the building when it is constructed or mounted later on as an addition [9, $15]$.

Wind turbines, according to their construction, are divided into two categories; horizontal wind turbines and vertical wind turbines (straight or angled). The rotor of the horizontal axis wind turbines is parallel to the ground. They are economical if they are installed in areas with high wind speeds [16]. Horizontal axis turbines have drawbacks due to the flexing system and generally cannot follow rapid and comprehensive changes. The wings of the vertical axis wind turbine are fixed perpendicular to the central axis. They are usually used in areas with low wind speeds. In such wind turbines, the direction of the wind is not important. Thanks to the wing structures, they can easily use the winds coming from every direction. They are mounted directly on the ground (soil level, building base, etc.). The construction is simple and light, easy to service with low post cost [2]. In parallel with the development of wind turbines, the presence of small vertical wind turbines, which can adapt to the direction of the wind on the constructions and reduce losses, have made it possible to prefer these types of turbines for use on the buildings. Principal vertical axis wind turbines are Darrieus, Giromill, and Savonius [16]. It is understood that the most appropriate wind turbine that can be used in the light of the above information may be a small vertical wind turbine.

\section{Electricity Generation by HRPSs}

Because renewable energy sources and energy production depend on natural conditions, continuity in the produced energy is not always ensured. For this reason, the creation of a hybrid power system using multiple sources of energy is considered. Hybrid renewable power systems (solar, wind, biomass, hydraulics, etc.) are designed as complementary units to meet the energy demand continuously $[17,18]$. To design a hybrid renewable power system, the energy generation system needs to know the potential of the existing renewable energy sources to be utilized. In addition, we need to know the energy demand at the facility. Therefore, energy planners need to investigate the sun, wind and other potential sources of energy in the region concerned, in addition to the planned use of energy. This approach can be used to design a hybrid power system capable of optimally meeting the energy demands of the respective facility or settlement [19].

\section{HRPS COMPONENTS FOR IGUVS}

\section{A. Energy Claim}

IGUVS is a 4-story building located in Istanbul Pendik. The latitude and longitude values at the time of construction are 400 54' 3.6" and 29013 ' 8.4' 'respectively. Fig. 2 shows the direction of the building and the front view of the structure. The front of the building is facing south-southwest. The elevation is $14 \mathrm{~m}$ up to the starting point of the building, and the corner heights are $16 \mathrm{~m}$. The width of the front is $52 \mathrm{~m}$. The total active area to be used for the PV panels is calculated as about $400 \mathrm{~m}^{2}$ when the windows and other gaps are deducted from the front edge of the structure. Satellite and front view of the IGUVS building can be seen in Fig. 2.

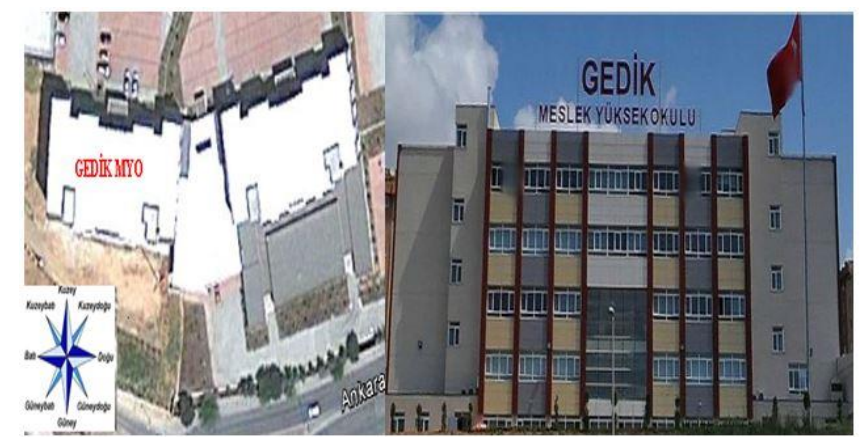

Fig.2. Satellite and front view of the IGUVS building.

The electricity consumption of the building was evaluated and the electricity consumption value was entered to the HOMER software as data on an hourly basis per year. The daily and hourly load values of IGUVS by using these values and HOMER software are shown in Fig. 3. HOMER software is a software that performs operations such as modeling, analysis and simulation of power systems, and sensitivity analysis, and was developed within the American National Renewable Energy Laboratory (NREL). The software allows the design of power systems as well as the comparison of power systems with each other. The hourly load data belonging to IGUVS was obtained by considering the monthly bills of the school. The daily rate is calculated as 376 $\mathrm{kWh} /$ day. The daily peak load is also calculated as $24 \mathrm{~kW}$. While the average hourly minimum load demand of IGUVS is 9.40 kWh between 19:00 - 06:00 hours, maximum hourly load demand is $17 \mathrm{kWh}$ between 16: 00-17: 00 hours.

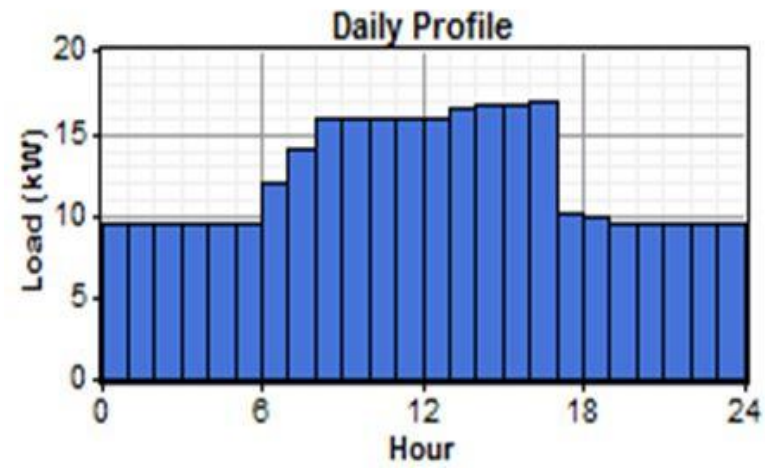

Fig.3. Hourly energy demand of the building. 


\section{B. Potential of Solar Energy}

Monthly average solar radiation $\left(\mathrm{kWh} / \mathrm{m}^{2}\right)$ values were taken from the nearest meteorological station to the province of Istanbul for the last 20 years [20]. Using these values, the solar radiation values and the clearness index of IGUVS using HOMER software are shown in Fig. 4. The annual average solar radiation value is calculated as $4.028 \mathrm{kWh} / \mathrm{m}^{2} / \mathrm{d}$ At HOMER, solar radiation data is synthesized using the Graham algorithm. The Graham algorithm is used by the HOMER program to obtain the solar radiation data entered into the program on a monthly average using latitude and longitude coordinates. The annual average clearness index is set at approximately 0.502 .

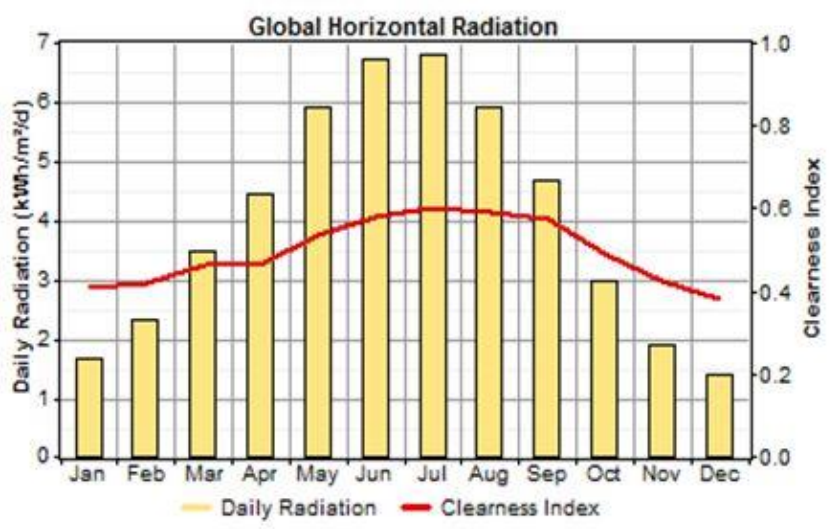

Fig.4. Monthly average solar radiation values.

\section{Wind Power Potential}

The monthly average wind speed $(\mathrm{m} / \mathrm{s})$ values for the last 20 years of Istanbul province are taken from the nearest meteorological station to the region [20]. The monthly average wind speed values of IGUVS using these values and HOMER software are shown in Fig. 5.

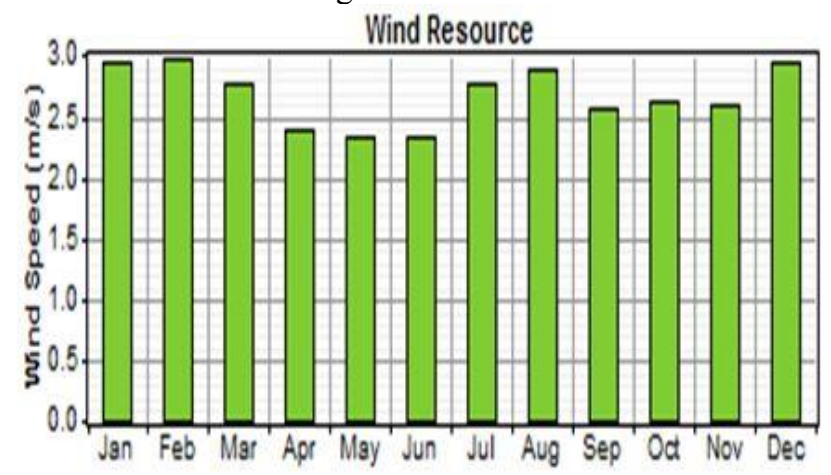

Fig.5. Average monthly wind speed.

\section{Hybrid Power System Components}

The components to be used in electricity production and their characteristics will be given in detail. The hybrid power system shown in Fig. 6 constitutes the energy production part, the wind turbine, and the solar panel unit. The system is powered by a grid to meet energy demands when wind and/or sun are inadequate [9]. In this hybrid power system, energy production is provided by wind turbines and solar panels. The energy will be supplied from the hybrid power system when wind and/or the sun is built on the level that can produce electricity. When there is not enough wind or sun, the building buys the energy demand from the network. Therefore, a clean electricity generation system with continuity has been established. Energy produced more than the demand will be sold to the national network. Two-way counters are used in these systems for this purpose. The aim here is the measurement of electricity consumption or the sale of excess energy sold to the network. Turkish law numbered 6094 and titled "Law on the Amendment of the Law on the Use of Renewable Energy Sources for the Purpose of Electricity Generation Production" allows the sale of the excess electricity to the network eliminating the need for a battery bank for energy storage in this system, which leads to a decrease in system installation cost $[21,22]$.

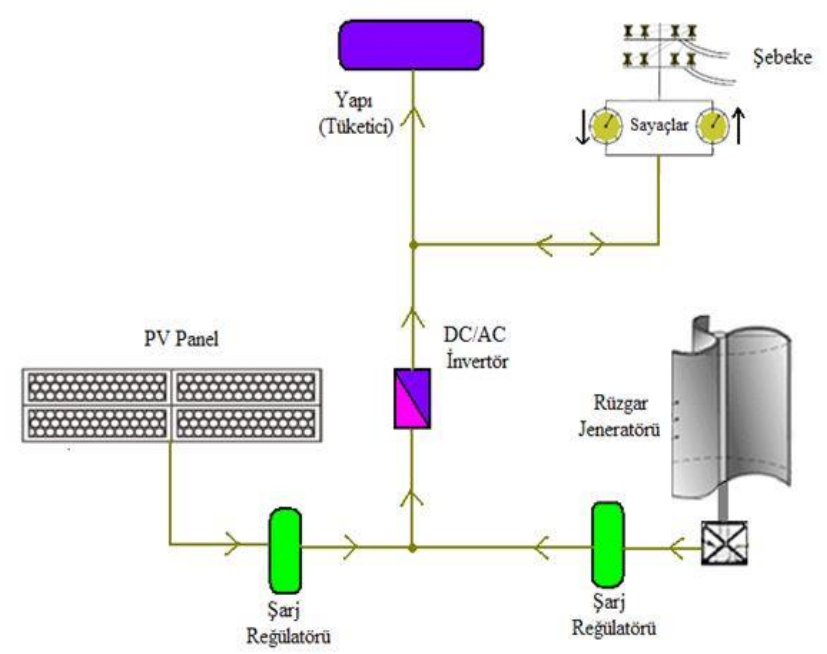

Fig.6. Single line schematic of a wind-solar hybrid power system.

\section{1) PV Panel}

The PV panel used in the hybrid power system is Sharp ND-Q235FD4-235 W. PV panel output power is $235 \mathrm{~W}$. The $\mathrm{PV}$ panel is one of the main energy providers in the hybrid system. The PV panel only generates energy during the time period from 06:00 to 18:00 and does not generate energy at other time intervals. The cost of the PV panel is about $\$ 500$, and the replacement cost is equal to the initial cost. The cost of operation and maintenance is negligible [23]. The number of PV panels varies from 0 to 10 .

\section{2) Wind Turbine}

The wind turbine used in the hybrid power system is one of the main energy providers of the system as is the PV panel. The wind turbine suggested here is a model that is not in the library of the HOMER software. The Savonius wind turbine with the vertical axis is used. The Savonius wind turbine consists of the data obtained as a result of tests performed in the laboratory environment with power parameters. It was entered as an external addition to HOMER. The Helix S594 model was used as the wind turbine. The initial cost of the wind turbine is about $\$ 17,500$. The output power of the wind 
turbine is $4.5 \mathrm{~kW}$. Wind turbine replacement costs were estimated at approximately $\$ 15,000$ and operation and maintenance costs at $\$ 500$ per year [24].

\section{3) Converter}

The power of the converter was chosen at the peak power of $24 \mathrm{~kW}$. It is used to transfer the power obtained from PV panels. The conversion efficiency is $90 \%$ and the initial cost is $655 \$ / \mathrm{kW}$. The replacement cost is equal to the initial cost. Operation and maintenance cost is negligible. Meanwell $\mathrm{DC} / \mathrm{AC}$ Solar Inverter is preferred as the converter [25].

\section{4) Network}

If the renewable energy sources in the hybrid power generation system cannot meet the load demand, the grid will meet the demand. Thus, continuity of energy is ensured. There are three different tariffs, which are called "triple tariff" [26].

\section{E. Operating Characteristics of the Hybrid Power System}

Operating characteristics of the hybrid power system are as follows:

Wind turbine and PV panel are the main energy providers. While the wind turbine is directly feeding the load, power produced by PV panels reaches the load by means of the power converter.

If the wind turbine and the PV panel cannot meet the demand, the grid will meet the demand.

Project life is set at 25 years.

The renewable energy ratio in the hybrid power generation system is expressed as a minimum of $40 \%$.

According to The Central Bank of the Republic of Turkey, the annual interest rate is $12 \%$ [27].

\section{DETERMINATION OF OPTIMUM HRPS FOR IGUVS}

\section{A. Sensitivity Analysis of HRPS}

It is the evaluation of which hybrid system is more optimal from alternative hybrid power generation systems when the wind speed values change between $2.67 \mathrm{~m} / \mathrm{s}$ and $5.5 \mathrm{~m} / \mathrm{s}$ and the solar radiation values change between $3 \mathrm{kWh} / \mathrm{m}^{2} / \mathrm{d}$ and 5.5 $\mathrm{kWh} / \mathrm{m}^{2} / \mathrm{d}$. The wind speed values and solar radiation values used in the sensitivity analysis are given in detail in Table 1.

TABLE I

EVALUATION OF WHICH HYBRID SYSTEM IS MORE OPTIMAL IN WHICHCASE

\begin{tabular}{|c|c|}
\hline $\begin{array}{c}\text { Solar radiation values } \\
\left(\mathbf{k W h} / \mathbf{m}^{2} / \mathbf{d}\right)\end{array}$ & $\begin{array}{c}\text { Wind speed values } \\
(\mathbf{m} / \mathbf{s})\end{array}$ \\
\hline 4.028 & 2.670 \\
\hline 3.000 & 3.500 \\
\hline 5.000 & 4.500 \\
\hline 6.000 & 5.500 \\
\hline
\end{tabular}

Besides, the optimum hybrid power generation system and optimal system configurations obtained in correspondence with the values given in Table 1 are detailed in Fig. 7. The optimum wind speed and solar radiation data for IGUVS are
$4.028 \mathrm{kWh} / \mathrm{m}^{2} / \mathrm{d}$ and $2.670 \mathrm{~m} / \mathrm{s}$, respectively. Considering these values, it is seen that the optimum hybrid renewable power generation system is a grid-connected wind/solar power system. The optimum configuration of this system was obtained as a $30 \mathrm{~kW}$ PV panel, $22.5 \mathrm{~kW}$ wind turbine, $50 \mathrm{~kW}$ Grid, and a $24 \mathrm{~kW}$ converter.

\begin{tabular}{|c|c|c|c|c|c|c|c|c|c|c|c|c|}
\hline $\begin{array}{c}\text { Solar } \\
\left.\mathrm{kWh} / \mathrm{m}^{2} / \mathrm{d}\right)\end{array}$ & $\begin{array}{l}\text { Wind } \\
(\mathrm{m} / \mathrm{s})\end{array}$ & 1甲大目 & $\begin{array}{c}\begin{array}{c}P V \\
(\mathrm{KW})\end{array} \\
\end{array}$ & Wind & $\begin{array}{l}\text { Conv. } \\
(\mathrm{kW})\end{array}$ & $\begin{array}{l}\text { Gind } \\
(\mathrm{kW})\end{array}$ & $\begin{array}{l}\text { Initial } \\
\text { Coptal }\end{array}$ & $\begin{array}{l}\text { Operating } \\
\operatorname{Cost}(S / y)\end{array}$ & $\begin{array}{l}\text { Total } \\
\text { NPC }\end{array}$ & $\mid$\begin{tabular}{|c|}
$\operatorname{COE}$ \\
$(\mathrm{S} / \mathrm{k} W \mathrm{Wh})$
\end{tabular} & $\begin{array}{l}\text { Ren. } \\
\text { Frac. }\end{array}$ & $\begin{array}{l}\begin{array}{l}\text { Capactly } \\
\text { Shotage }\end{array} \\
\end{array}$ \\
\hline 4.028 & 2.670 & & 30 & 5 & 24 & 50 & $\$ 235.720$ & 3.953 & $\$ 286.247$ & 0.164 & 0.56 & 0.00 \\
\hline 4.028 & 3500 & & 30 & 5 & 24 & 50 & $\$ 235,720$ & 3953 & $\$ 286247$ & 0.164 & 067 & 0.00 \\
\hline 4.028 & 4.500 & l畐 & & 5 & 24 & 50 & $\$ 40,720$ & 1.573 & $\$ 60.824$ & 0.035 & 0.63 & 0.00 \\
\hline 4.028 & 5.500 & 大国 & & 5 & 24 & 50 & $\$ 40.720$ & 1.573 & $\$ 60.824$ & 0.035 & 0.72 & 0.00 \\
\hline 4.028 & 6.500 & 狊 & & 5 & 24 & 50 & $\$ 40.720$ & 1.573 & $\$ 60.824$ & 0.035 & 0.76 & 0.00 \\
\hline 3.000 & 2.670 & 图 & 30 & 5 & 24 & 50 & $\$ 235.720$ & 3.953 & $\$ 286.247$ & 0.164 & 0.51 & 0.00 \\
\hline 3.000 & 3.500 & & 30 & 5 & 24 & 50 & $\$ 235.720$ & 3.953 & \$ 286.247 & 0.164 & 0.64 & 0.00 \\
\hline 3.000 & 4.500 & 图 & & 5 & 24 & 50 & $\$ 40.720$ & 1.573 & \$ 60.824 & 0.035 & 0.63 & 0.00 \\
\hline 3.000 & 5.500 & 石图 & & 5 & 24 & 50 & $\$ 40.720$ & 1.573 & $\$ 60.824$ & 0.035 & 0.72 & 0.00 \\
\hline 3.000 & 6.500 & & & 5 & 24 & 50 & $\$ 40.720$ & 1.573 & s 60.824 & 0.035 & 0.76 & 0.00 \\
\hline 5.000 & 2670 & 兽 & 30 & 5 & 24 & 50 & $\$ 235,720$ & 3.953 & $\$ 286.247$ & 0.164 & 0.59 & 0.00 \\
\hline 5.000 & 3.500 & & 30 & 5 & 24 & 50 & $\$ 235,720$ & 3.953 & $\$ 286.247$ & 0.164 & 0.70 & 0.00 \\
\hline 5.000 & 4.500 & & & 5 & 24 & 50 & $\$ 40.720$ & 1,573 & $\$ 60.824$ & 0.035 & 0.63 & 0.00 \\
\hline 5.000 & 5.500 & 图 & & 5 & 24 & 50 & $\$ 40.720$ & 1.573 & s 60.824 & 0.035 & 0.72 & 0.00 \\
\hline 5.000 & 6.500 & 园 & & 5 & 24 & 50 & $\$ 40.720$ & 1.573 & $\$ 60.824$ & 0.035 & 0.76 & 0.00 \\
\hline 6.000 & 2.670 & 兽 & 30 & 5 & 24 & 50 & $\$ 235.720$ & 3.953 & S286.247 & 0.164 & 0.60 & 0.00 \\
\hline 6.000 & 3.500 & 5 & 30 & 5 & 24 & 50 & $\$ 235.720$ & 3.953 & S 286.247 & 0.164 & 0.71 & 0.00 \\
\hline 6.000 & 4.500 & $\hat{\mathrm{f}}$ & & 5 & 24 & 50 & S 40.720 & 1.573 & \$ 60.824 & 0.035 & 0.63 & 0.00 \\
\hline 6.000 & 5.500 & & & 5 & 24 & 50 & $\$ 40.720$ & 1.573 & \$ 60,824 & 0.035 & 0.72 & 0.00 \\
\hline 6.000 & 6.500 & & & 5 & 24 & 50 & $\$ 40.720$ & 1.573 & $\$ 60,824$ & 0.035 & 0.76 & 0.00 \\
\hline 7.000 & 2.670 & & 30 & 5 & 24 & 50 & $\$ 235.720$ & 3.953 & $\$ 286.247$ & 0.164 & 0.61 & 0.00 \\
\hline 7.000 & 3.500 & & 30 & 5 & 24 & 50 & $\$ 235.720$ & 3.953 & S 286.247 & 0.164 & 0.71 & 0.00 \\
\hline 7.000 & 4.500 & 1 图 & & 5 & 24 & 50 & $\$ 40.720$ & 1.573 & \& 60.824 & 0.035 & 0.63 & 0.00 \\
\hline 7.000 & 5.500 & l & & 5 & 24 & 50 & $\$ 40.720$ & 1.573 & $\$ 60.824$ & 0.035 & 0.72 & 0.00 \\
\hline 7.000 & 6.500 & & & 5 & 24 & 50 & $\$ 40.720$ & 1.573 & \& 60.824 & 0.035 & 0.76 & 0.00 \\
\hline
\end{tabular}

Fig.7. Optimum hybrid power system options for each wind speed and solar radiation data.

Fig. 8 shows that the optimum system is the Grid/Wind hybrid power generation system when the wind speed is 4.5 $\mathrm{m} / \mathrm{s}$ or higher with all values of the solar radiation. With lower wind speed, the optimum hybrid system will be the Grid/Wind/PV system.

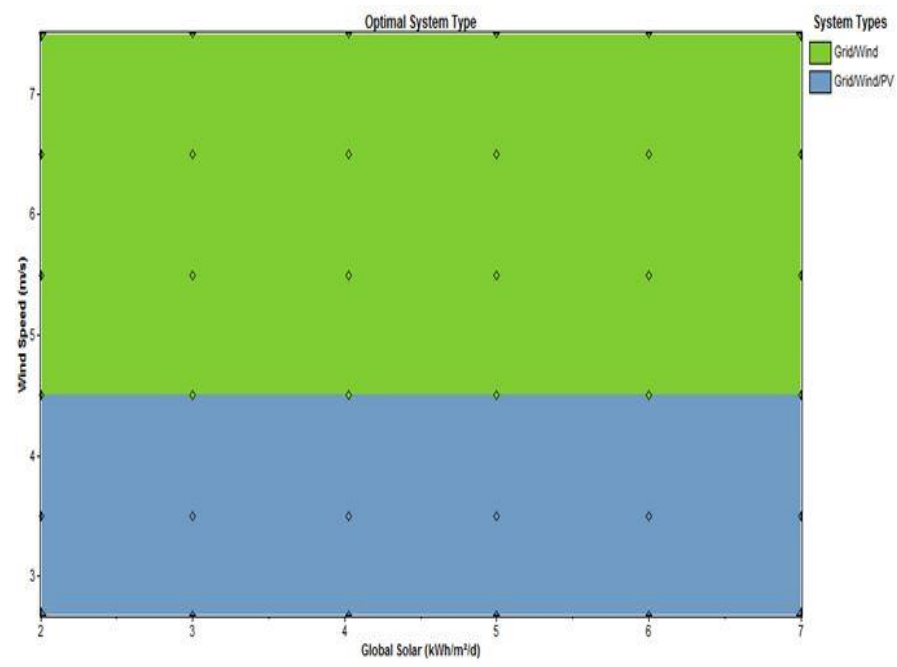

Fig.8 Sensitivity analysis.

In these cases, the total installation cost and the unit cost of energy are the lowest. It is the optimum value with a unit energy cost of $0.164 \$ / \mathrm{kWh}$.

\section{B. Economic Analysis of the Hybrid Renewable Power System}

As a result of optimization performed considering the optimum values of wind speed and solar radiation data for Gedik Vocational School, unit energy cost is calculated as 
$0.164 \$ / \mathrm{kWh}$. The initial capital was $\$ 235,720$ and the operating cost was $\$ 4000$. The total net present cost was $\$$ 286,242. The distribution of this cost among the components of the hybrid renewable power generation system is shown in Fig. 9 in detail.

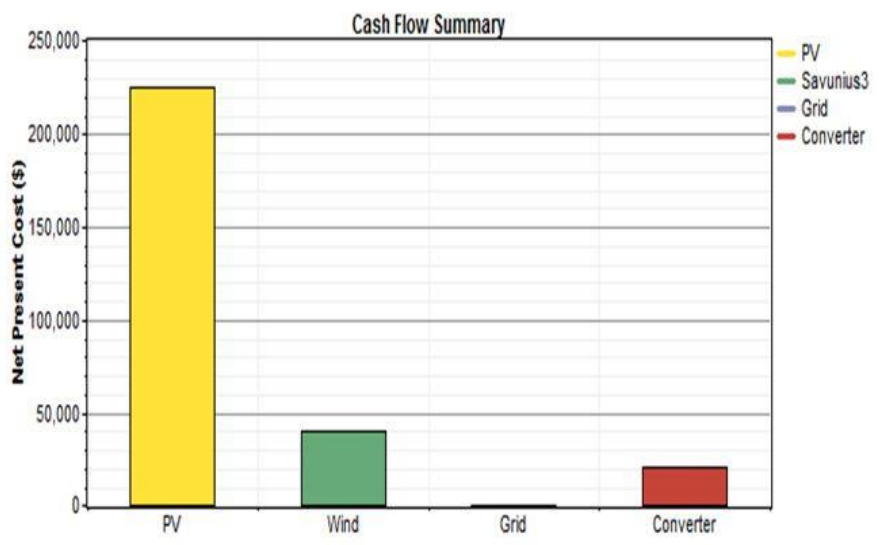

Fig. 9 Cost summary.

\section{Analysis of Electricity Generation and Consumption}

As shown in Fig. 10, annual electricity generation from PV panels is $35,575 \mathrm{kWh} /$ year while yearly electricity generation from wind turbines is $49,294 \mathrm{kWh} /$ year.

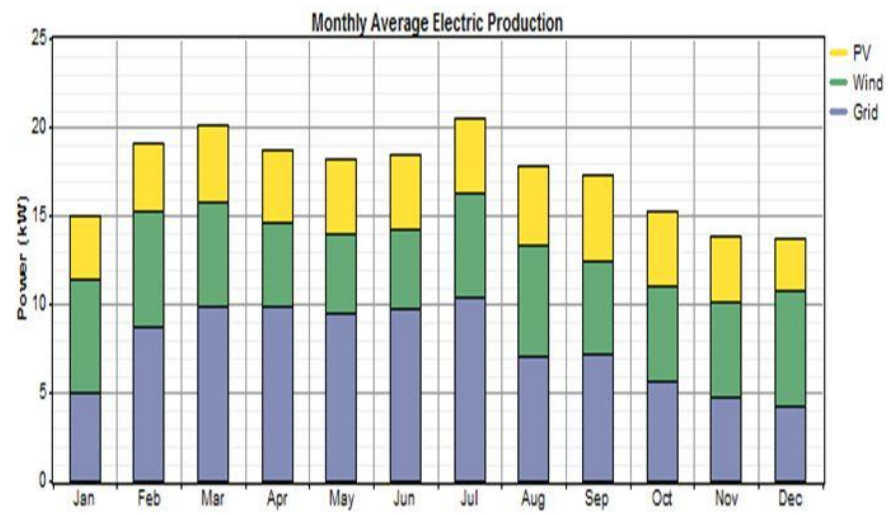

Fig.10 Monthly average electricity production by source types

Finally, the annual amount of energy supplied from the network stands at $66,834 \mathrm{kWh} /$ year. The total amount of electricity needed for the building is $151,703 \mathrm{kWh} /$ year. In this case, the PV panels provide $23 \%$ of the demand while the wind turbine provides $32 \%$ and the network $44 \%$. In other words, $44 \%$ of the electricity demand is generated by the grid and $53.4 \%$ by the renewable energy sources. The annual electricity consumption of the building is $136,510 \mathrm{kWh} /$ year, and the sales-ready excess electricity is $5,367 \mathrm{kWh} /$ year. The residual energy is $2,405 \mathrm{kWh} /$ year, $1.59 \%$, which is in the acceptable range and corresponds to the other losses of the system.

\section{Emission Status of Hybrid Power System}

The construction requires $136,510 \mathrm{kWh} /$ year of electrical energy per year. Emission values can easily be calculated in
HOMER software. Before simulating the power system, HOMER determines the emissions factor $(\mathrm{kg}$ of pollutant emitted per unit of fuel consumed) for each pollutant. After the simulation, it calculates the annual emissions of that pollutant by multiplying the emissions factor by the total annual fuel consumption [28]. When this energy is supplied from the network, atmospheric emissions of about $236 \mathrm{~kg}$ of greenhouse gas emission per day are achieved, with $\mathrm{CO}_{2}$ emissions of $86,274 \mathrm{~kg} /$ year for $\mathrm{SO}_{2}$ and $183 \mathrm{~kg} /$ year for $\mathrm{NO}_{2}$. However, with the grid-connected hybrid renewable solar/wind power system, these values are $38047 \mathrm{~kg} /$ year $\mathrm{CO}_{2}$ emissions of $168 \mathrm{~kg} /$ year $\mathrm{SO}_{2}$ and $82.4 \mathrm{~kg} /$ year $\mathrm{NO}, 106$ $\mathrm{kg}$ /day of carbon dioxide emissions per day. When the proposed grid-connected renewable solar/wind power system is preferred, there is a $45 \%$ reduction in greenhouse gas emission. It is also a fact that the system is a renewable, clean and environmentally friendly hybrid power system.

\section{CONCLUSION}

The findings obtained as a result of this study are given below:

It is planned to design vertical wind turbine on top of the Gedik Vocational School building and PV panels to be vertically mounted, unlike conventional horizontal installation. In this context, system modeling has been carried out.

Optimum wind speed and solar radiation data for Gedik Vocational School are $4.028 \mathrm{kWh} / \mathrm{m}^{2} / \mathrm{d}$ and $2.670 \mathrm{~m} / \mathrm{s}$ respectively. Considering these values, it seems that the optimum hybrid renewable power generation system is a gridconnected wind / solar power system.

Optimum system configuration is a $30 \mathrm{~kW}$ PV panel, 22.5 $\mathrm{kW}$ wind turbine, $50 \mathrm{~kW}$ Grid, and $24 \mathrm{~kW}$ converter.

The unit energy cost of the optimal hybrid power generation system is calculated as $0.164 \$ / \mathrm{kWh}$. Besides, the initial cost was $\$ 235,720$, and the operating cost was $\$ 4,000$. The total net present cost was $\$ 286,242$.

A reduction in greenhouse gas emission of $45 \%$ is obtained when a grid-connected hybrid renewable solar/wind power system is preferred. It is also a fact that the system is a renewable, clean and environmentally friendly hybrid power system.

With the optimum hybrid power generation system, the renewable hybrid energy system meets the yearly electricity demand required by the building, with $23 \%$ solar panel, $32 \%$ wind turbine, and the renewable hybrid energy system meets $55 \%$ of the annual electricity demand of the designed hybrid system.

As a result of the sensitivity analysis, it is seen that the optimum system is the Grid/Wind hybrid power generation system when the wind speed is $4.5 \mathrm{~m} / \mathrm{s}$ and above with all values of the solar radiation, and the optimum hybrid system in all other cases is the Grid/Wind/PV system. 


\section{REFERENCES}

[1] J.S. Ojo, P.A. Owolawi, A.M. Atoye, "Designing a Green Power Delivery System for Base Transceiver Stations in Southwestern Nigeria", SAIEE Africa Research Journal, Volume 110, March 2019, pp. $19-25$.

[2] S. Sayin, "The Significance of the use of renewable energy in our country's building sector and the opportunities of utilizing of solar energy in buildings", Selcuk Univ. M.Sc. Thesis; 2006.

[3] T. Adefarati, R.C. Bansal, "Application of renewable energy resources in a microgrid power system", The Journal of Engineering, 2019, pp.5308-5313.

[4] I. Das, C.A. Cañizares, "Renewable Energy Integration in Diesel-Based Microgrids at the Canadian Arctic", Proceedings of the IEEE, Volume 107, Sept. 2019, pp. 1838-1856.

[5] M. Altın, "Research on the Architectural Use of Photovoltaic (PV) Components in Turkey from the Viewpoint of Building Shape", Dokuz Eylul Univ. Ph.D. Thesis; 2005.

[6] H.U.R Habib, S. Wang, M.R. Elkadeem, M.F. Elmorshedy, "Design Optimization and Model Predictive Control of a Standalone Hybrid Renewable Energy System: A Case Study on a Small Residential Load in Pakistan", IEEE Access, Volume 7, August 2019, pp. 117369117390 .

[7] IEA Renewable energy: 2018. https://www.iea.org/topics/renewables/Accessed08.07.2018

[8] R. Singh, R.C. Bansal, "Optimization of an Autonomous Hybrid Renewable Energy System Using Reformed Electric System Cascade Analysis", IEEE Transactions on Industrial Informatics, Volume 15, Jan. 2019, pp.399-409.

[9] O. Akar, "Technical and Economical Analysis of Renewable Energy Resources Based Electricity Generation And Usage In Smart Buildings", Marmara Univ. M.Sc. Thesis; 2011.

[10] I. Yuksek, T. Esin, "Possibilities of Using Renewable Energy Resources in Buildings", 5thInternational Advanced Technologies Symposium (IATS’ 09), Karabuk, 2009.

[11] A. Parida, S. Choudhury, D. Chatterjee, "Microgrid Based Hybrid Energy Co-Operative for Grid-Isolated Remote Rural Village Power Supply for East Coast Zone of India”, IEEE Transactions on Sustainable Energy, Volume 9, no 3, July 2018, pp.1375-1383.

[12] A. Kumar, A.R. Singh, Y. Deng, X. He, P. Kumar, R.C. Bansal, "Multiyear Load Growth Based Techno-Financial Evaluation of a Microgrid for an Academic Institution", IEEE Access, Volume 6, June, 2018, pp.37533-37555.

[13] G. Celebi, "Principles of Use of Photovoltaic Panels in Building Vertical Shells", Gazi University Journal of Faculty of Engineering and Architecture, 2002, pp. 17-33.

[14] G. Kocaslan, "Energy resources in Turkey and the research of wind energy as an alternative technology", Istanbul Univ. M.Sc. Thesis, 2002.

[15] M.H. Gunel, H.E.Ilgın, "Use of Wind Energy as an Architectural Design Criteria", Journal of Ege Architecture. Izmir, 6-11; 2008.

[16] G.V.J. Bussel, S.M. Mertens, "Small Wind Turbines for The Built Environment. The Fourth European\& African Conference on Wind Engineering", ITAMASCR, 11-15 July,1-9; 2005.

[17] B. Dursun, "Determination of the optimum hybrid renewable power generating systems for Kavakli Campus of Kirklareli University", Turkey. Renewable and Sustainable Energy Reviews. 2012; 16, pp.6183-6190.

[18] S.B. Efe, B. Kocaman, "Physical Realization and Analysis of Renewable Energy-Based Hybrid System", 5th International Symposium on Innovative Technologies in Engineering and Science 29-30 September 2017 (ISITES2017) Baku, Azerbaijan, 2017.

[19] B. Dursun, C. Gokcol, I. Umut, E. Ucar, S. Kocabey, "TechnoEconomic Evaluation of a Hybrid PV-Wind Power Generation System", Intern. Journ. of Green Energy, 2013; pp. 117-136.

[20] Istanbul Meteorology 1st Division Directorate, Monthly average wind speed and global radiation values of the last 20 years, Turkish State Meteorological Service Report, Istanbul, 2011.

[21] N. Koca, "Using hybrid energy at home", Sakarya Univ. M.Sc. Thesis, 2006.

[22] O. Akar, U.K. Terzi, "Building Based Micro Distributed Power Generation Systems", 3e Electrotech Journal. 223, pp. 210-220,2013.22

[23] Sharp Electronics Corporation, 2015.
http://files.sharpusa.com/Downloads/Solar/Products/sol_dow_NDQ235F 4.pdf.Accessed 08.07.2018

[24] Swepic, 2018.

http://www.swepinc.com/pdf/Wind\%20Turbines/Vertical\%20Axis\%20 Wind\%20Turbines/Helixwind\%20S594.pdf. Accessed 08.07.2018

[25] Mean Well, 2018. http://www.meanwell.com/webapp/product/search.aspx?prod=tn-3000, Taiwan, Accessed 08.07.2018

[26] P. Yilmaz, M.H. Hocaoglu, A.E.S. Konukman "A Pre-feasibility Case Study on Integrated Resource Planning Including Renewables", Energy. Policy, 2008.

[27] The Central Bank of the Republic of Turkey Exchange Rates, 2018. http://www.tcmb.gov.tr/wps/wcm/connect/en/tcmb+en.Accessed 08.07.2018

[28] How HOMER Calculates Emissions, 2019.

https://www.homerenergy.com/products/pro/docs/latest/how_homer_cal culates_emissions.html.Accessed 28.10.2019

\section{BIOGRAPHIES}

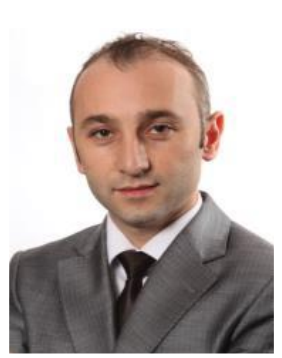

Onur AKAR was born in Giresun in 1981. $\mathrm{He}$ received his B.S. degree from Electrical Education Department of Technical Education Faculty of University of Marmara, Istanbul, in 2005 and his M.Sc. degree from Electrical Education Department of Institute of Pure and Applied Sciences, University of Marmara, İstanbul, in 2011. He also received B.S degree from Electrical and Electronics Engineering Department of Engineering Faculty of Karadeniz Technical University, Trabzon, in 2017. He has been currently attending doctorate programme in Electrical and Electronics Engineering department of Institute of Pure and Applied Sciences of Marmara University, Istanbul.

$\mathrm{He}$ has been working as a Lecturer at Mechatronics Program of Vocational High School of Istanbul Gedik University since 2010. He served as the Head of Electrical Department of Vocational High School of Gedik University in Istanbul between 2012 and 2015. He is the author of 2 article and one book chapter. His research interests include Control Systems, Renewable Energy Systems and Power Systems.

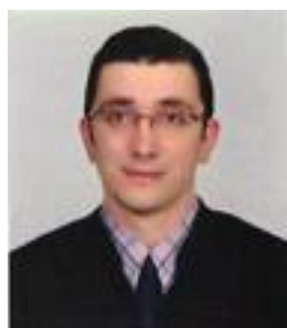

Umit K. TERZI was born in Zonguldak in 1968. He received his B.S. degree from Electrical Education Department of Technical Education Faculty of University of Marmara, Istanbul, in 1989 and his M.Sc. and Ph.D. degree from Electrical Education Department of Institute of Pure and Applied Sciences, University of Marmara, Istanbul, in 1994 and 2000 respectively.

From 1989 to 1996, he worked as a research assistant, from 1996 to 2000 as a lecturer, from 2000 to 2013 as an Assistant Prof. Dr. for university of Marmara. Since 2013 he has been working as an Associate Prof. Dr. for Electrical and Electronics department of Technology Faculty of Marmara University and Electrical Education Department of Technical Education Faculty where he is head of department. 
His research interests include Electrical Machinery, Power Systems, Energy Transmission and Distribution, Renewable Energy Systems.

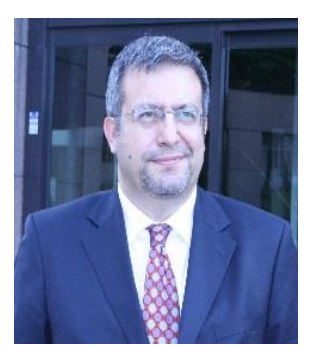

B. Koray TUNCALP was born in Istanbul in 1962. He received his B.S. degree from Electrical Education Department of Technical Education Faculty of University of Marmara, Istanbul, in 1984 and his M.Sc. and Ph.D. degree from Electrical Education Department of Institute of Pure and Applied Sciences, University of Marmara, Istanbul, in 1988 and 1999 respectively.

From 1984 to 1993, he worked as a research assistant, from 1993 to 1999 as a lecturer, from 1999 to 2001 as an Assistant Prof. Dr., from 2001 to 2003 as an Associate Prof. Dr., from 2003 to 2014 as an Prof. Dr. in two departments for University of Marmara. Since 2015 he has been working as an Prof. Dr. for Electrical and Electronics Engineering Department of School of Engineering, also is Director of Vocational School of Halic University.

His research interests include Electrical Energy Measurement, Mechatronics, Instrumentation, E-learning, Vocational and Technical Education.

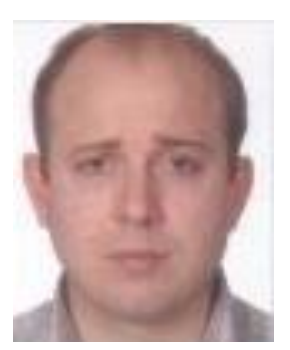

Temel SONMEZOCAK was born in Edirne in 1978. He graduated his B.S. degree from Electrical Education Department of Technical Education Faculty of University of Marmara, Istanbul, in 2001. In 2015, he completed his M.Sc. degree at Istanbul Aydin University, Department of Electrical and Electronics Engineering. In 2016, he started his Ph.D. program in Electronics Engineering at Yildiz Technical University and still continues. Since 2018, he has been working as a lecturer in Electrical department of Istanbul Gedik University.

His research interests include lighting systems, power electronics and renewable sources. 